\title{
A Study on Interpersonal Meaning in Communicative Discourse Analysis
}

\author{
Li Jian \\ School of Foreign Language, Shandong Women University, Jinan, Shandong, China
}

\begin{abstract}
The research on communicative discourse based on Systemic-functional linguistics is in accordance with the development tendency of discourse analysis. Through a detailed study on how to embody the interpersonal meaning by discourse, it is concluded that modality system occupies an important position on communicative discourse. This study provides a theoretical basis for language learners to master the competence on how to express utterance and construct a discourse. It finally aims to improve the output and communicative competence of foreign language learners, and to elicit the educational illumination on communicative writings.
\end{abstract}

Keywords - discourse analysis, modality system, interpersonal meaning

\section{交际实用英语话语分析的人际意义研究}

\author{
李 健 \\ 山东女子学院外国语学院, 济南, 山东, 中国
}

\begin{abstract}
摘 要 在韩礼德的系统功能语言学的理论基础上, 对交际实用性英语进行话语分析, 是顺应话语分析领域的发展趋势。通过具 体研究话语怎样体现以及用哪些方式体现其人际意义, 推论出情态系统在体现人际语篇中占据重要位置。这为交际学习者掌握准确表 达话语和进行语篇建构提供科学理据, 进而应用到实际语言交际中, 最终提高语言的输出能力和交际能力。对交际应用文写作的教与 学也具有指导意义。
\end{abstract}

关键词 话语分析, 情态系统, 人际意义

\section{1. 话语分析的人际意义概述}

“话语分析”这一术语是由美国结构主义语言学家 Harris 在他发表于 1952 年美国《语言》杂志的一篇文章中 首次使用的, 它从 20 世纪 60 年代中期开始成为一个独立 的研究领域。 80 年代后, 话语分析研究得到长足发展, 其 代表人物 Van Dijk (1981) 主编的《语篇》和 Roy O. Freedle 主编的《话语过程》成为这一领域的专业学术杂志。话语 分析作为学科发展, 可归纳为以下几个趋势: 1) 从把话语 作为类似于句子、词等单位的物体到把话语放置在社会文 化语境中; 2) 从书面到口头, 篇章研究与话语研究的融合; 3）功能语法理论对其影响力增长很快; 4) 从话语作为一 个总体到各类话语的研究; 5) 从文学作品到实用性话语的 研究；6）话语人际意义的研究。

话语的人际意义来自功能语法(Halliday 1985) 中对语 言元功能的划分, 更强调语言的人际的、变化的和可商议 的意义, 这与传统语言学研究中只关注形式和意义之间对
等的、稳定的语义关系有很大不同。这种趋势不是突然形 成的, 而是对语言应用的人际方面的意识逐渐发展的自然 结果。将系统功能语法理论与话语分析相结合的代表作是 韩礼德(Halliday) 的《功能语法引论》。

功能语言学认为语言除具有表达讲话者的亲身经历和 内心活动功能外, 还具有表达讲话者的身体、地位、态度、 动机和他对事物的推断等功能, 即语言的“人际功能”。发 话人在陈述和疑问中对自己提出的命题的有效性的判断, 在命令中要求对方承担的义务和在提供中要表达的个人意 愿, 这些社会角色关系一般都由情态系统来体现。语言学 家认为, 情态能表现作者或说话人的评价或态度（Fowler, 1979: 85); 可以把情态意义看作是发话人对命题的真实性 的判断 (Quirk et al., 1985: 219)。客观上, 真实性存在归向 极的问题, 非此即彼、不是即非。但在主观上, 发话人或 者出于某些特殊原因, 或是缺乏对命题足够的证据而避免 走极端, 说出的话便是中有非, 非中有是, 情态意义就是 
指是非之间的度（李基安,1999:21）。情态所表达的是在归 向极之间存在的不同等级的可能性, 即存在许多中间类型 的非绝对性的句子, 它们便是情态句。情态是体现人际意 义的语气系统中的一个子系统, 是表现人际功能的主要实 现手段, 它在人际元功能中的重要性使它成为分析特定体 裁话语的人际功能时的中心概念。所以, 研究话语的人际 意义所主要关注的即是对情态系统的研究。

\section{2. 情态系统的分类和表达}

韩礼德等人(1994: 89) 把情态句分为两种: 情态和意 态。情态是说话人对命题可能性的判断, 包括可能性阶 (possible, probable, certain) 和通常性阶(sometimes, usually, always)。意态是说话人对命题可希望性的判断, 包括责任 性阶(allowed, supposed, required) 和倾向性阶(willing, keen, determined)。韩礼德给这些形式赋予了价值, 在每一个阶 中, 第一项价值低, 第二项为中值, 第三项为高值。(转引 李战子 2000: 8)

在传统语法中, 情态就是一系列情态助动词所表达的 意义。系统功能语言学认为情态一般由下列方式来表达:

(1) 情态助动词, (如: may, can, must, shall, will, could, might, should, would, need, dare 等)

(2) 情态附加成分, (如: already, still, yet, soon 等与时态有 关, not, so, yes, no 与归向极有关, of course, surely, absolutely, actually 等与语气有关, 以及评注性附加成 分: unfortunately, hopefully 等)

(3) 谓语的扩展, (如: be supposed to, be obliged to, be anxious to 等)

(4) 情态隐喻: 第一人称代词为载体, (如: I think, I guess, I believe, I'm sure 等)

(5) 非第一人称代词载体, (如: It's obvious, It's required, Everyone admits that...等)

（6）情态名物化结构, (如: There's a possibility that..., There's a certainty that...等)

(7) 介词短语, (如: in my opinion, to my mind, in all probability, to some degree 等)

\section{3. 情态话语的人际功能}

\section{1 表达主观性和客观性}

韩礼德区分了情态话语的两种向度: 主观与客观。主 观性、客观性以及价值观是情态系统所表达的最明显的内 容。一般来说, 大部分情态助动词、情态隐喻 (以第一人 称代词为载体) 及介词短语, 所涉及的可能性属于发话人 个人想象世界里的东西, 使命题具有主观性, 因而表达主 观情态意义。如例句所示:

\section{(1) I think Mary is right.}

(2) In my opinion, Mary is right.

(3) You should get up early.

(4) I'm sure we are late

(5) She might have finished her paper.

使用“谓语的扩展形式”可以表达发话人对命题评价的 客观性情态意义。在下面的例句中, 说话人似乎表现出对 受话人施加的压力和责任毫无关系, 使人感觉到压力来自 于另外的渠道, 而不是说话人自己, 从而体现出明确的客 观性:

(6) You are assumed to carry out the plan immediately.

(7) You are required to pay for it before this Sunday.

“名物化结构”和“情态隐喻”的不以第一人称代词为载 体的关系过程小句也能表达情态的明确客观意义, 如:

(8) There's a possibility that the bridge will be repaired next month.

(9) There's a certainty that we will be late.

(10) It's obvious that Mary is right.

(11) It's likely that we will win.

这样的结构消除了说话人明显的主观性, 使其断言似 乎不再是个人的观点而是一个固有特征, 从而隐藏了情态 来源, 使人感觉到说话人是依赖客观事实的可能性而不是 说话人自己的主观想象, 让人难以提出质疑。

韩礼德 (1994: 357) 还在主客观的取向方面细分为 4 种: 明确主观、非明确主观、明确客观和非明确客观。

(12) a. I think/I'm certain that Mary is right. (明确主观) a1. In my opinion, Mary is right. (明确主观)

b. Mary must/may/could/might be right. (非明确主观)

c. Mary is probably/possibly right. (非明确客观)

d. It's likely/obvious that Mary is right. (明确客观)

$\mathrm{d}_{1}$.There's a possibility that Mary is right. (明确客观)

\section{2 情态隐喻表达明确主观和明确客观性}

情态隐喻与明确的主客观表达有紧密联系。根据例 (12), 可以归纳出：像 “I think”, “I'm certain”, “I'm willing” 这样的句子做主句时, 表达说话人的明确主观意愿; 像 "It's obvious", “It's likely", "You can't doubt that...", “Everyone admits that...", “There's a possibility that...”这样 的句子做主句时，表达说话人的明确客观倾向。

情态隐喻的研究在语篇分析中具有十分重要的意义。 如上所述, 情态意义体现了说话者看待某命题或提议的角 度。为达到某种特殊的目的或效果, 说话人有时会故意采 用明确主观隐喻形式, 强调自己的看法或判断的不确定性。 有时这种明确的主观取向反映出会话双方的权利关系或情 
感卷入程度。例如, 人们在向陌生人或比自己身份高的人 表达不同意见时, 常使用明确的主观隐喻形式, 表示客气 或对方的尊重, 如:

(13) I think that might be an unrealistic idea.

说话者也会采用明确客观的隐喻形式, 通过隐藏真正 的情态来源, 以使自己的判断或断言客观化, 使人难以提 出异议或拒绝。如以上 3.1 中的例 (8)-(11)。

\section{3 满足礼貌原则}

如上所说, 话语中的情态具有多重人际意义, 既可表 示认知上的不确定性, 又可满足礼貌原则的要求, 可加强 不同立场之间的多声的协商的可能性。在语境一定的情况 下, 话语所含情态意义的强弱在很大程度上影响话语的礼 貌程度。Palmer 和 Perkins (见 Leech 1983: 29 转引 李杰, 钟永平 2002:12) 把“情态动词”分为两类: 主情态动词和从 属情态动词。主情态动词是现在时形式的情态动词, 如 can, may, must, will, shall 等; 从属情态动词是过去时形式的情 态动词, 如 could, might, would, ought to, should。Perkins 认为从属情态动词比主情态动词更具情态意义, 因而也就 更加礼貌。不同的情态意义表达了说话人对所谈主题不同 的感情和态度。

依照以上论述, 所有的情态表达方式都存在值高或值 低的问题。就情态助动词来说, 可以根据其所表示意义的 强弱程度将它们归入不同的类型。主情态动词, 如 will, shall, can, may 比其“过去形式”表示的意义要强烈一些, 其值就 相应高一些; 而 must 和 have to 没有过去形式, 则不存在 这样的划分, 但它们的意义最强烈, 因而所含的值最高。 由此可用下面的图表来表示 (李杰等 2002:13)

\begin{tabular}{|c|c|c|c|c|}
\hline 高 & \multicolumn{2}{|r|}{ 中 } & \multicolumn{2}{|c|}{ 低 } \\
\hline Must & Will & Would & Can & Could \\
\hline Have to & shall & Should/ought to & may & might \\
\hline
\end{tabular}

情态隐喻也存在情态值高低的问题, 比如在我们常用 的表达方式中, I think 的情态值居中, I believe 的值最高, I guess 最低。值高的语气最为强烈, 表明说话人的肯定和武 断, 给受话人留下的余地微乎其微; 而值低的意义仅表示 说话人的猜想而已, 语气最为温和。

在言语交流中, 情态值的高低同礼貌程度有密切的关 系。以上的分析表明, 情态值越高, 说话人对于命题所持 的态度就越趋于肯定。相反, 情态值越低, 话语的语气就 越委婉, 受话人对是否顺从于发话人的意志就有较大的选 择余地, 这就相当于常说的给别人一点面子。

礼貌同情态的主客观性也有关系。如果说话人既希望
使用相同价值的情态形式，而又不至于使人听起来感到不 够礼貌, 他就会采用客观性的情态表达。使对方不会感到 约束或压力, 即使是拒绝了, 也不会感到为难。这样就能 给受话人留有充分的回旋余地, 以便有更多的空间对话语 效度进行争论。

\section{4.交际实用语篇人际意义的体现与表达一情态的使用}

交际实用语篇, 即交际应用文, 指在日常生活或工作 中经常应用的文体, 它强调社交方面的写作, 因此以书信 往来的形式居多。下面主要讨论以社交信函为主要形式的 英语应用文，其分类大致有：请求、询问、邀请、回应、 接受、拒绝、道歉、感谢、恭贺、慰问、投诉等形式。

如上所述, 情态系统表达人际功能, 是人际功能的重 要语义载体或实现手段。情态系统分析在语篇研究中占有 重要的作用。因此, 在社交信函这样的人际意义十分明显 的社交语篇中, 情态词汇的使用显得尤为重要。

\section{1 情态助动词的使用}

社交英语信函的一大主要特点是情态动词的大量使 用, 以表示对对方的客气与尊重, 满足礼貌的要求。因而, 从属情态助动词的使用频率较多。例如, 在表示请求、询 问、邀请、接受等信函中, 经常出现诸如下列的句子: “Would you be so kind as to..." "Would you be kind enough to...", "I'd like to know if it's possible to....", "I'd like to extend to you an invitation to....", "I would be delighted to accept your...”这样的句子表示双方的关系比较陌生, 或者为表 示信函的正式以及对事件的重视程度, 所用语气较委婉, 因此使用情态值低的助动词。那么, 如果双方关系比较熟 悉, 信函的形式就不必非常正式, 可以使用值较高的助动 词, 如: “Can I....”, “Could/Would you....”, “How about...”, "We hope to see you...", "I will be happy to accept your..."。

\section{2 其他情态类型的使用一 交际写作的策略要求}

除使用情态助动词外, 其他形式的情态也经常使用, 以满足不同类型社交信函的需要。据上述分析, 在向陌生 人或比自己身份高的人表达不同意见时, 采用明确的主观 隐喻, 可强调自己的看法或判断的不确定性, 也满足礼貌 的要求。例如在接受请求并且提出建议的信函中, 可用这 样的句子: “I think there is some merit in your offer...”, “In my opinion, your suggestion is a delightful...”。而明确的客 观隐喻形式经常用在表示拒绝和道歉的信函中, 表现出对 受话人施加的压力和责任毫无关系, 使人感觉到压力来自 于另外的渠道, 从而体现出客观性, 达到拒绝的目的。但 是只采用这样的形式是不够的, 因为社交信函的特点决定 
必须满足礼貌的需要, 在做到明确拒绝的同时, 还需对此 表示遗憾和抱兼, 因此, 其他的情态形式 (尤其是主观性 的语句）也要配合使用。如下面一则拒绝信所示:

\section{Dear Jenny,}

Thank you for your invitation to your university graduation ceremony on July 5 . Unfortunately, much as I would like to be there at this important moment in your life, I cannot possibly take that day off as I am now all tangled up in a difficult lawsuit and booked for a meeting with my lawyer on the very day of the ceremony. Though I called him to ask for rescheduling the appointment, it was simply impossible for him to change the date on his calendar. I am sorry for not being able to be there with you on that day, but I promise I will come over to your house at the weekend to give you my congratulation in person.

在这篇拒绝信中, 作者先通过使用 Unfortunately, much as I would like to 的主观表达取向表示对拒绝抱有遗憾; 通 过使用 I cannot possibly.... it was simply impossible for him 的客观表达取向表示拒绝的必要性, 用 I am sorry for not being able to... 这样的主观句表示道歉; 最后通过使用 I promise I will... 情态值高的助动词和主观隐喻表达对此事 的态度及处理方法, 恰当的解决问题, 解除双方的顾虑, 使双方关系没有因此次拒绝而受到干扰和破坏。

另外, 在表示感谢、恭贺、慰问以及投诉的信函中, 由于事件以及涉及的感情色彩比较单一, 所使用的情态形 式不如拒绝信和道歉信复杂, 一般只使用主观取向的情态 形式, 同时由于语气的加重与肯定, 会采用情态值较高的 形式。如在感谢信中, 常使用以下句子: “Thanks so much for...", "I'm witting to thank you for...", "Please accept my sincere appreciation of...” 在恭贺信中, 会采用诸如 “I congratulate you on...", "I just cannot wait to tell you how happy I am for you." "I'm proud of you....", “I'm sure you will...” 这样的主观句来表达欣喜、祝贺以及鼓励之情。在 慰问信中,经常采用诸如 “I'm sorry/upset/shocked to hear that...", "Please accept my sympathies...", "I can't tell you how much I feel for you...", "Take good care of yourself and don’t worry about...”, “I will...”, “I hope...” 等表达主观取 向的语句和祈使句来表示惋惜、遗憾以及安慰、关怀之情。
而在投诉信中, 投诉者对事件不满的态度、以及希望解决 问题的强烈愿望, 决定在信中使用情态值更高的主观情态 句式。如:“I'm writing to complain about...”, “I’m completely disappointed at what...", "I believe...", "I sincerely hope...", "I am eagerly looking forward to...."。

\section{5. 结论}

功能语言学认为语言具有表意、人际、语篇等三大元 功能, 人际元功能关注的是篇章作者和篇章意图中的读者 的互动关系, 即说话人用语言表达自己的态度, 并影响听 者的态度和行为。这一功能承载着很重的语义负荷, 它的 词汇语法手段是语气和相关的情态种类、加重表达和其他 评价性的手段, 它们是在整个篇章中实现的。情态作为人 际元功能的主要语义载体, 获得了超越逻辑和传统语法的 重要地位 (李战子 2000:8)。英语情态是一个十分复杂的系 统, 因此在研究情态意义时不能只拘泥于形式。在语言学 界, 情态意义的各类划分从来就没有一致过。正是因为情 态意义的多样性恰恰反映了人的情感的多样性。系统功能 语言学对情态的研究, 相对于传统语法的研究, 跨越了一 大步, 对我们更好地了解英语情态系统的结构特点, 掌握 好情态的用法, 更准确、更礼貌、更委婉地表达自己的言 语具有实际的指导意义。

\section{参考文献(References)}

[1] Fowler, R.et al. Languageand Control. London: Routledge \& Kegan Paul, 1979. 85, 203.

[2] Halliday, M.A.K. An Introduction to Functional Grammar. London: Edward, 1985/1994.

[3] Leech, G. Principle of Pragmatics. London: Longman, 1983. 29, 108

[4] Quirk, R. et al. A Comprehensive Grammar of the English Language. London: Longman Group Limited, 1985.219.

[5] Li Zhanzi. Modality - The Spread From Sentence to Discourse. Foreign Language Publication 2000(4): 7-12.

[6] Li Ji An. Significance of Modality and Modal Auxiliary. Foreign Languages 1999(4): 19-23.

[7] Li Jie \& Zhong Yongping. On English Modal System and Its Functions . Foreign Languages Teaching. 2002(1): 9-14. 